\title{
Changes in the antioxidative enzyme activities and lipid peroxidation in wheat seedlings exposed to cadmium and lead stress
}

\author{
Surjendu K. Dey*, Jayashree Dey, Sanjukta Patra and Debasmita Pothal \\ Department of Environmental Sciences, Fakir Mohan University, Vyasa Vihar, Balasore-756019, India. *Corresponding \\ author: surjendufmu@ rediffmail.com
}

Received: 05 February 2007; Returned for revision: 27 March 2007; Accepted: 21 June 2007

\begin{abstract}
Wheat seedlings were grown in presence of $\mathrm{CdCl}_{2}(0-200 \mu \mathrm{M})$ and $\mathrm{Pb}\left(\mathrm{NO}_{3}\right)_{2}(0-2000 \mu \mathrm{M})$ separately. The growth of metaltreated seedlings was significantly depressed. The activities of antioxidative enzymes namely superoxide dismutase (SOD), catalase (CAT) and guaiacol peroxidase (POX) were altered both in root and shoot tissues of 7-d-old seedlings. Under Cd stress, SOD activity in roots was undetectable even at the lowest Cd concentration $(50 \mu \mathrm{M})$ whereas in shoots it declined sharply with increasing Cd levels. The activity of CAT declined to a greater extent in roots than in shoots. Even though the POX activity increased nine times in shoots, a decreasing trend was observed in root tissues due to $\mathrm{Cd}$ stress. Under Pb stress, the induction in SOD activity and decline in CAT activity were sharper in root tissues than in their shoot counterparts. The POX activity increased both in roots and shoots under Pb stress. Malondialdehyde concentration increased in both roots and shoots of $\mathrm{Cd}$ - and $\mathrm{Pb}$-treated seedlings. The results suggest that metal toxicity was associated with oxidative stress. The decline in CAT activity may be the probable reason behind the Cdand $\mathrm{Pb}$-induced oxidative stress, since the alterations in SOD and POX activities showed different trends under these metal stresses.
\end{abstract}

Key words: catalase, heavy metals, peroxidase, superoxide dismutase, Triticum

\begin{abstract}
Alterações nas atividades de enzimas antioxidantes e peroxidação de lipídeos em plântulas de trigo expostas a cádmio e chumbo: Plântulas de trigo foram cultivadas na presença de $\mathrm{CdCl}_{2}(0-200 \mu \mathrm{M})$ e $\mathrm{Pb}\left(\mathrm{NO}_{3}\right)_{2}(0-2000 \mu \mathrm{M})$, isoladamente. $\mathrm{O}$ crescimento das plântulas tratadas com $\mathrm{Cd}$ e $\mathrm{Pb}$ foi significativamente reduzido. As atividades de enzimas antioxidantes, dismutase do superóxido (SOD), catalase (CAT) e peroxidase do guaiacol (POX) foram alteradas tanto em raízes como na parte aérea nas plântulas com $7 \mathrm{~d}$ de idade. Sob estresse de Cd, não se detectou atividade de SOD nas raízes, mesmo na menor concentração de $\mathrm{Cd}$ testada $(50 \mu \mathrm{M})$, enquanto a atividade da enzima, na parte aérea, decresceu apreciavelmente com o incremento nos níveis de Cd. A atividade da CAT diminuiu, porém mais nas raízes que na parte aérea. A atividade de POX aumentou nove vezes na parte aérea, porém decresceu nas raízes, em resposta ao estresse de Cd. Sob estresse de $\mathrm{Pb}$, a indução da atividade de SOD e o declínio da atividade de CAT foram mais expressivos nas raízes que na parte aérea. A atividade da POX aumentou tanto nas raízes como nas folhas sob estresse de $\mathrm{Pb}$. A concentração de aldeído malônico aumentou tanto nas raízes como na parte aérea das plântulas tratadas com $\mathrm{Cd}$ ou $\mathrm{Pb}$. Os resultados sugerem que a toxicidade causada pelos metais foi associada com estresse oxidativo. O declínio da atividade da CAT deve ter tido um papel preponderante nesse contexto, haja vista que as alterações nas atividades da SOD e POX mostraram diferentes padrões sob as condições de estresse causadas por esses dois metais.
\end{abstract}

Palavras-chave: catalase, dismutase do superóxido, metais pesados, peroxidase, Triticum

Braz. J. Plant Physiol., 19(1):53-60, 2007 


\section{INTRODUCTION}

Nowadays, development has become synonymous with deforestation and progress has become synonymous with pollution. Because of the increased mining and industrial activities in the late $19^{\text {th }}$ and early $20^{\text {th }}$ century, the pollution due to heavy metals has increased considerably worldwide. Among the different heavy metals, cadmium $(\mathrm{Cd})$, lead $(\mathrm{Pb})$ and mercury $(\mathrm{Hg})$ are considered as the most toxic in the environment (Landis and Yu, 1999; Oliveira da Silva et al., 2005). Cadmium and $\mathrm{Pb}$ are hazardous heavy metal pollutants that are released to the environment from various sources of modern human activities (Eick et al., 1999; Sanita di Toppi and Gabrielli, 1999). Since most of the activities involving these metals are indispensable for today's life, the environmental contamination and specifically the soil contamination with $\mathrm{Cd}$ and $\mathrm{Pb}$ is not likely to drop off in the near future. Even though these metals are not essential for plants, because of their water solubility they are readily absorbed by the root systems. The growth and metabolisms of plants are adversely effected by the increasing levels of these metals in the soil environment (Kastori et al., 1992; Balestrasse et al., 2003). Besides that, the metals are also accumulated in different plant parts and thereby enter into the food chain. Therefore, pollution due to heavy metals is significant from nutritional and environmental point of view.

Plants are very often subjected to a variety of environmental stresses that are known to generate reactive oxygen species (ROS) and create oxidative stress situations (Elstner et al., 1988; Baisak et al., 1994; Shah et al., 2001). The pollutant metals are involved in different ROS generating mechanisms within the cells (Stohs and Bagchi, 1995) and thereby induce oxidative stress. Both $\mathrm{Cd}$ and $\mathrm{Pb}$ can enhance the prooxidant status of the cell by reducing the antioxidant glutathione (GSH) pool, activating calcium-dependent systems and affecting iron-mediated processes (Pinto et al., 2003). These metals are also known to interrupt the photosynthetic electron transport chain which leads to generation of superoxide and singlet oxygen (Asada and Takahashi, 1987). The effects of $\mathrm{Cd}$ - and $\mathrm{Pb}$-induced oxidative stress in plants have been reported in the forms of either increase or decrease in the antioxidative enzyme activities and alterations in the levels of antioxidant molecules (Chaoui et al., 1997; Malecka et al., 2001; Schutzendubel et al.,
2001). In most of the studies the antioxidative efficiency under metal stress has been documented either in roots or in shoots. But reports on the changes in the antioxidative efficiency both in roots and shoots due to $\mathrm{Cd}$ - and $\mathrm{Pb}$ induced oxidative stress under identical experimental conditions are very scarce. Therefore, in this study attempts have been made to find the possible reason behind $\mathrm{Cd}$ - and $\mathrm{Pb}$-induced oxidative stress in wheat seedlings by assessing the activities of antioxidative enzymes like superoxide dismutase (SOD, EC 1.15.1.1), catalase (CAT, EC 1.11.1.6) and guaiacol peroxidase (POX, EC 1.11.1.7), both in roots and shoots under identical experimental conditions.

\section{MATERIAL AND METHODS}

Growth of plant material and imposition of heavy metal stress: Wheat (Triticum aestivum L. cv. Sonalika) seeds of uniform size were selected and surface sterilized with freshly prepared filtered 3\% solution of commercial bleaching powder (calcium oxychloride) for $30 \mathrm{~min}$, followed by washings for several times with distilled water. The seeds were then germinated on moist filter paper in Petri dishes in the dark and after $24 \mathrm{~h}$, uniform seeds were transferred to nylon nets stretched over small plastic containers containing $150 \mathrm{~mL}$ solutions of different concentrations of cadmium chloride $\left(\mathrm{CdCl}_{2}\right)$ and lead nitrate $\left(\mathrm{Pb}\left(\mathrm{NO}_{3}\right)_{2}\right)$, prepared with distilled water. The metals were studied separately to observe their independent effects on the plants. The concentrations used for Cd were 50, 100, 200, 500, 1000 and $2000 \mu \mathrm{M}$ and that for $\mathrm{Pb}$ were 200, 500, 1000 and $2000 \mu \mathrm{M}$. Distilled water, without any metal, was used as control. Twenty germinated seeds were kept on each container to maintain the uniformity of the growth condition and stress imposition. The plants were grown with $8 \mathrm{~h}$ light/16 h dark cycle, at $30 \pm 1^{\circ} \mathrm{C}$, under a photosynthetic photon flux density of $c a .90 \mu \mathrm{mol} \mathrm{m} \mathrm{m}^{-2} \mathrm{~s}^{-1}$ at the surface of the nylon net. Seven-day-old seedlings (6 d of exposure to heavy metals) were sampled from all the treated and control containers and root and shoot tissues were collected separately for biochemical analyses.

Evaluation of seedling vigour: To assess the effects of $\mathrm{Cd}$ and $\mathrm{Pb}$ on growth, 7-d-old seedlings were collected and root and shoot lengths were measured. The values were compared with those of the control plant. 
Extraction and estimation of soluble protein: Root and shoot tissues were homogenized separately with cold 50 $\mathrm{mM}$ sodium phosphate buffer under ice-cold conditions, and the resulting homogenates were centrifuged at $0^{\circ} \mathrm{C}$ at $17,000 \mathrm{~g}$ for $10 \mathrm{~min}$. An equal volume of $20 \%(\mathrm{w} / \mathrm{v})$ trichloroacetic acid (TCA) was added to the supernatants and these were kept overnight in a refrigerator to facilitate complete precipitation of soluble protein. The samples were then centrifuged at $1900 \mathrm{~g}$ for $15 \mathrm{~min}$ and the pellets washed successively with $10 \%$ cold TCA, ethyl alcohol, ethyl alcohol: chloroform (3:1, v/v), ethyl alcohol: ether $(3: 1, \mathrm{v} / \mathrm{v})$ and finally with ether. The pellets were evaporated to dryness and solubilized by resuspending with $0.3 \mathrm{~N} \mathrm{NaOH}$ for $16 \mathrm{~h}$ at $37^{\circ} \mathrm{C}$. The samples were centrifuged and supernatants collected for protein estimation following the method of Lowry et al. (1951), using BSA as standard.

Extraction and estimation of malondialdehyde (MDA): The level of lipid peroxidation was measured by estimating MDA, a decomposition product of peroxidized polyunsaturated fatty acid component of membrane lipid, using thiobarbituric acid (TBA) as the reactive material following the method of Heath and Packer (1968). The tissues were homogenized with $5 \%(\mathrm{w} / \mathrm{v}) \mathrm{TCA}$ and $1 \mathrm{~mL}$ of homogenate was mixed with $4 \mathrm{~mL}$ of TBA reagent $(0.5 \%$ of TBA in $20 \%$ TCA). The reaction mixtures were heated at $95^{\circ} \mathrm{C}$ for $30 \mathrm{~min}$ in a water bath and then quickly cooled in an ice bath and centrifuged at $1900 \mathrm{~g}$ for $10 \mathrm{~min}$. The absorbance of the coloured supernatant was measured at $532 \mathrm{~nm}$ and was corrected for non-specific absorbance at $600 \mathrm{~nm}$ and for absorbance at $532 \mathrm{~nm}$ of the correction blank. For the reference blank $1 \mathrm{~mL}$ of $5 \%$ (w/v) TCA was mixed with $4 \mathrm{~mL}$ TBA reagent and for the correction blank $1 \mathrm{~mL}$ of tissue homogenate was mixed with $4 \mathrm{~mL}$ of TBA reagent $20 \%(\mathrm{w} / \mathrm{v})$ TCA. Concentration of MDA was calculated by using the extinction coefficient of 155 $\mathrm{mM}^{-1} \mathrm{~cm}^{-1}$ for MDA at $532 \mathrm{~nm}$.

Enzyme extraction and assay: Root and shoot tissues were homogenized under ice-cold conditions in extraction buffers containing $10 \%$ (w/v) insoluble PVPP. The buffers used were: $50 \mathrm{mM}$ sodium phosphate buffer, $\mathrm{pH} 7.4$ for SOD, and $50 \mathrm{mM}$ sodium phosphate buffer, $\mathrm{pH}$ 7.5 for CAT and POX. The homogenates were centrifuged at $17,000 \mathrm{~g}$ for $10 \mathrm{~min}$ at $0^{\circ} \mathrm{C}$. The resulting supernatants were desalted by passing through gel filtration columns, packed with pre-soaked Sephadex G-25 (fine grade). The eluted fractions were tested for protein and the fractions responding to the test were pooled and used directly for the assay of the enzyme. Superoxide dismutase was assayed by measuring the inhibition of superoxidedriven nitrite formation from hydroxylamine hydrochloride, as formulated by Das et al. (2000). The enzyme activity was calculated from the value of $\mathrm{V}_{0} / \mathrm{V}-1$, where $\mathrm{V}_{\mathrm{o}}$ is the absorbance (read at $543 \mathrm{~nm}$ ) of the control (without enzyme) and $\mathrm{V}$ is the absorbance of the sample (with enzyme). Catalase was assayed by measuring the decrease in the $\mathrm{H}_{2} \mathrm{O}_{2}$ concentration at $240 \mathrm{~nm}$ (Aebi, 1974) and the activity was calculated by using the extinction coefficient of $40.0 \mathrm{mM}^{-1} \mathrm{~cm}^{-1}$ for $\mathrm{H}_{2} \mathrm{O}_{2}$ at $240 \mathrm{~nm}$. Peroxidase was assayed using guaiacol and $\mathrm{H}_{2} \mathrm{O}_{2}$ as the substrates. The increase in absorbance due to tetraguaiacol formation was recorded at $470 \mathrm{~nm}$ as described by Kar and Feierabend (1984); the activity was calculated using the extinction coefficient of $26.6 \mathrm{mM}^{-1}$ $\mathrm{cm}^{-1}$ due to tetraguaiacol formation.

Presentation of data and statistical analysis: One unit of SOD was defined as the amount that inhibits the superoxide-driven nitrite formation from hydroxylamine hydrochloride by $50 \%$ under the assay conditions. Activities of CAT and POX were expressed in katals, i.e., one mole of substrate consumed or product formed per second. All the experiments were performed at least for three times with three replicates each time. The mean values are presented with the SD. The significance of difference between means (of either root or shoot tissues for a particular parameter, not between root and shoot tissues) was computed following the LSD test (Gomez and Gomez, 1984).

\section{RESULTS}

Relative to control plants, growth of the wheat seedlings was drastically reduced due to $\mathrm{Cd}$ and $\mathrm{Pb}$ at all tested concentrations (Figure 1). For Cd, there was an almost complete inhibition of growth from $200 \mu \mathrm{M}$ onwards; even at $50 \mu \mathrm{M} \mathrm{Cd}$, growth was inhibited ( 60\%) in both roots and shoots. Therefore, all the analytical studies were restricted to treatments in the range of 0-200 
$\mu \mathrm{M}$ of $\mathrm{Cd}$. For $\mathrm{Pb}$, growth of roots and shoots was significantly reduced, even at the lowest concentration $(200 \mu \mathrm{M})$. At $2000 \mu \mathrm{M}$ of $\mathrm{Pb}$ lengths of both shoot and root were very small and growth was almost fully inhibited.

In control seedlings, SOD activity was lower in roots than in shoots (Figure 2). With increasing $\mathrm{Cd}$ concentration, there was a sharp decline in SOD activity
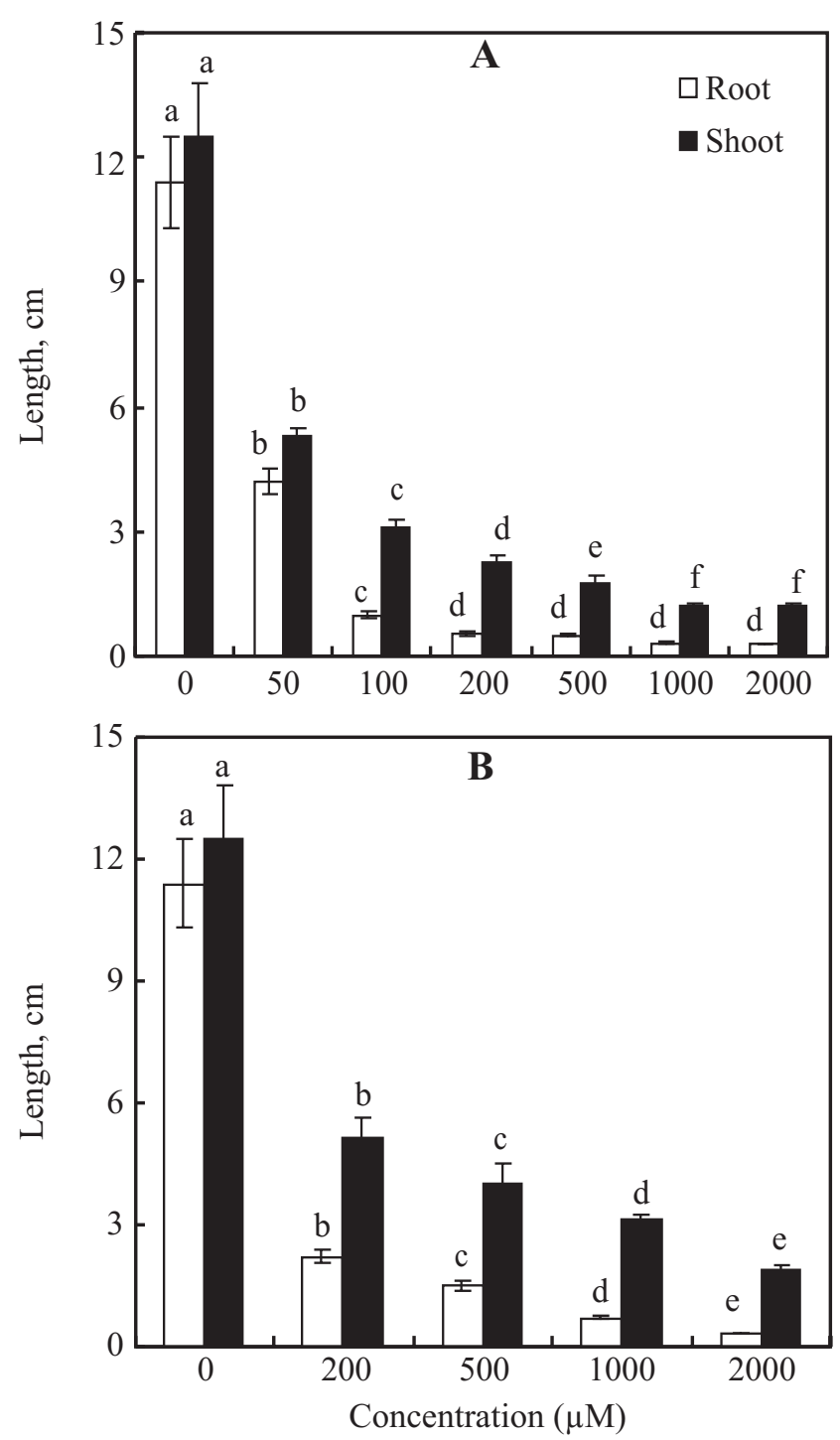

Figure 1. Changes in the root and shoot length of 7-d-old wheat seedlings grown in presence of incresing concentrations of $\mathrm{CdCl}_{2}(\mathbf{A})$ and $\mathrm{Pb}\left(\mathrm{NO}_{3}\right)_{2}(\mathbf{B})$, separately. The values are the mean \pm SD of three independent experiments each with three replicates. The mean values, of a particular tissue type (either root or shoot), followed by the same letter are not significantly different $(P \leq 0.05$; LSD test). in shoot tissues, reaching significance even at the lowest Cd concentration tested $(50 \mu \mathrm{M})$, whereas in root tissues there was a complete loss of SOD activity starting from 50 $\mu \mathrm{M}$ onwards. The activity of CAT nearly halved in roots at $50 \mu \mathrm{M}$ of $\mathrm{Cd}$, and thereafter small changes were noted at higher $\mathrm{Cd}$ concentrations (Figure 2). By contrast, in shoot tissues the decline in CAT activity was not so sharp; e.g., it was $32 \%$ at $200 \mu \mathrm{M}$ of $\mathrm{Cd}$. The trends in POX activity were different in root and shoot tissues. Roots of control plants had 58 times more POX activity than shoot tissues. With the imposition of Cd stress, POX activity declined in roots but ultimately increased ninefold in shoots, in comparison with control plants (Figure 2).

There were alterations in the activities of all three enzymes in wheat plants grown under $\mathrm{Pb}$ stress (Figure 3). The SOD activity increased both in root and shoot tissues with increasing $\mathrm{Pb}$ concentrations. However it should be noted that although roots of control plants had lower SOD activity than that of shoots, with the imposition of metal stress the increase in SOD activity in roots was remarkably sharper than in shoots; at $2000 \mu \mathrm{M}$ of $\mathrm{Pb}$, enzyme activity in root tissues was about three times higher than that in shoot tissues. The CAT activity declined significantly with $\mathrm{Pb}$ stress, but to a greater extent in roots than in shoots. In contrast, POX activity showed an opposite trend, i.e. it increased both in root and shoot tissues as the concentrations of $\mathrm{Pb}$ increased in the growth medium. In general, at all the concentrations, roots had a much higher POX activity than that of shoots.

Malondialdehyde concentration was enhanced both in root and shoot tissues with the severity of metal stress (Figure 4). However, Cd-induced increased MDA accumulation reached statistical significance only at 200 $\mu \mathrm{M}$ of $\mathrm{Cd}$. For $\mathrm{Pb}, \mathrm{MDA}$ was significantly larger in root tissues at 1000 and $2000 \mu \mathrm{M}$ than in control plants whereas in shoots such difference started occurring at $200 \mu \mathrm{M} \mathrm{Pb}$, but with no appreciable change at higher concentrations.

\section{DISCUSSION}

In the present study, the most prominent symptom of $\mathrm{Cd}$ (as well as $\mathrm{Pb}$ ) toxicity was found to be the stunted growth of 7-d-old seedlings. Like other stresses, Cd stress is also expected to alter the activities of 

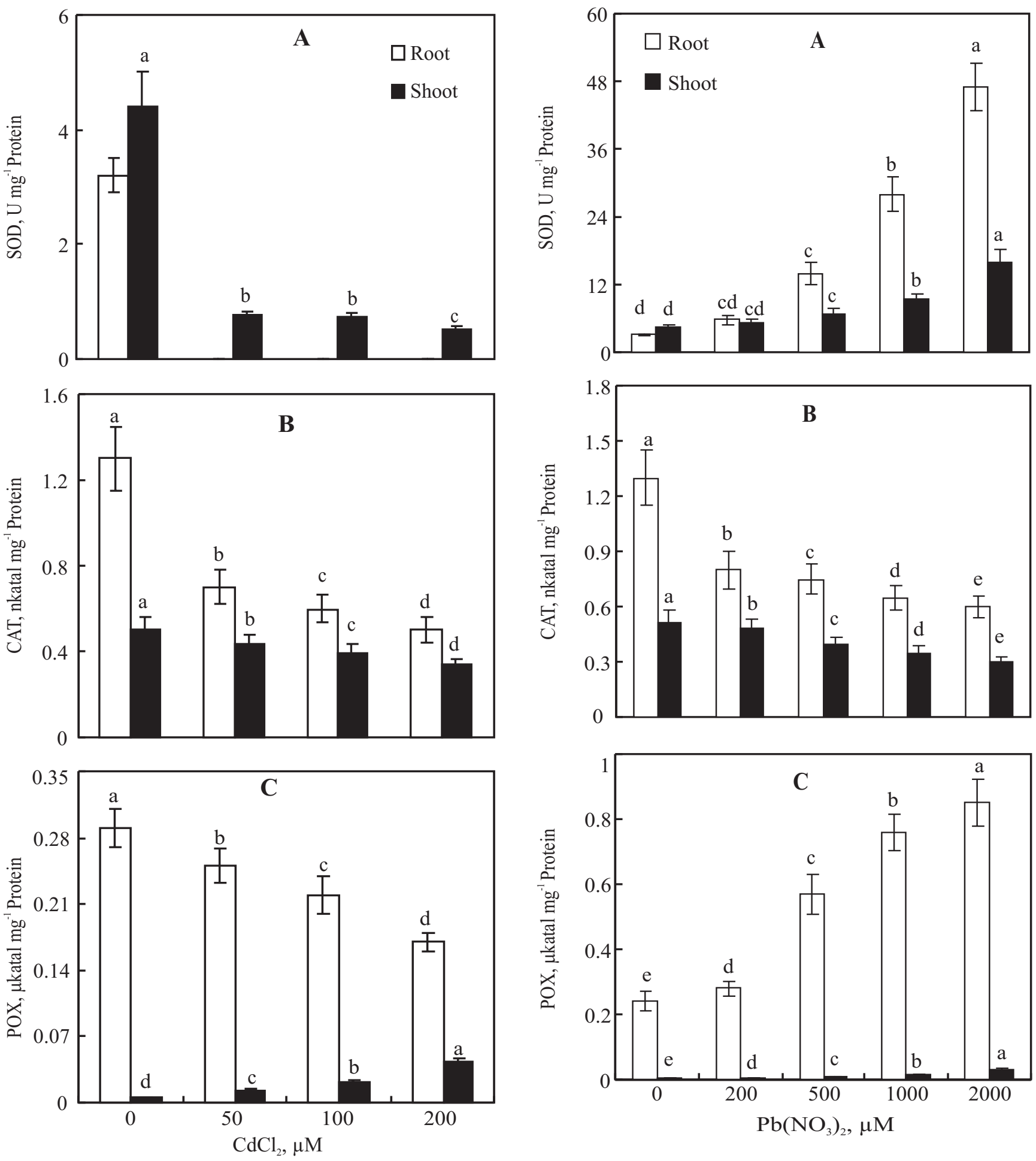

Figure 2. Changes in the specific activities of superoxide dismutase (SOD) (A), catalase (CAT) (B) and guaiacol peroxidase $(\mathrm{POX})(\mathbf{C})$ in root and shoot tissues of 7-d-old wheat seedlings grown in presence of incresing concentrations of $\mathrm{CdCl}_{2}$. See legend to Figure 1 for details.

Figure 3. Changes in the specific activities of superoxide dismutase (SOD) (A), catalase (CAT) (B) and guaiacol peroxidase $(\mathrm{POX})(\mathbf{C})$ in root and shoot tissues of 7-d-old wheat seedlings grown in presence of increasing concentrations of $\mathrm{Pb}\left(\mathrm{NO}_{3}\right)_{2}$. See legend to Figure 1 for details. 

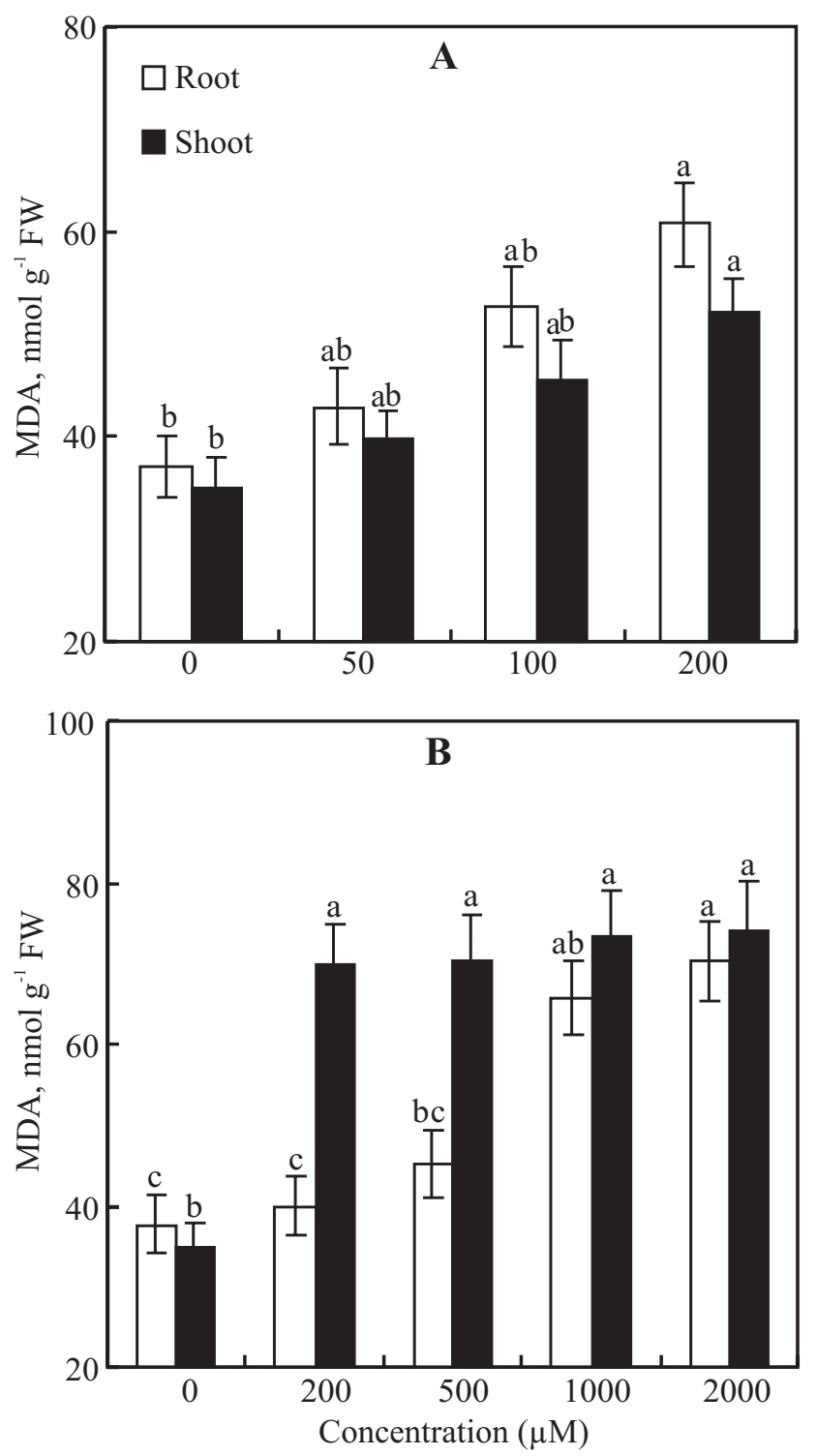

Figure 4. Changes in lipid peroxidation in root and shoot tissues of 7-d-old wheat seedlings grown in presence of different concentrations of $\mathrm{CdCl}_{2}(\mathbf{A})$ and $\mathrm{Pb}\left(\mathrm{NO}_{3}\right)_{2}(\mathbf{B})$, separately. See legend to Figure 1 for details.

antioxidative enzymes and thereby creating an oxidative stress situation. Superoxide dismutase, CAT and POX are important antioxidative enzymes that function in the cells to prevent the build-up of ROS (Elstner, 1982; Halliwell and Gutteridge, 1999). Superoxide dismutase destroys superoxide, forming $\mathrm{H}_{2} \mathrm{O}_{2}$ which in turn may be detoxified by CAT and POX. As a result, the formation of the hydroxyl radical is prevented since it is produced by the interaction of superoxide and $\mathrm{H}_{2} \mathrm{O}_{2}$, being catalyzed by transition metal ions (Elstner, 1982). A very sharp decline in SOD activity in shoot tissues and its complete loss in root tissues, as well as the decrease in CAT activity (Figure 2), indicate the weakening of superoxide and $\mathrm{H}_{2} \mathrm{O}_{2}$ scavenging systems due to $\mathrm{Cd}$ stress. In addition, the decreased POX activity in roots may also be responsible for the poor efficiency to decompose $\mathrm{H}_{2} \mathrm{O}_{2}$ in Cd-treated roots. Even in shoots where POX increased remarkably under Cd stress, its activity may not be linked to efficient $\mathrm{H}_{2} \mathrm{O}_{2}$ scavenging. This is because guaiacol peroxidases are localized in cytosol, cell wall, vacuole and in extracellular spaces and induction of activity under $\mathrm{Cd}$ stress might be due to increased release of cell-wallbound peroxidases, as has been observed earlier under various stress situations (Mittal and Dubey, 1991; Zhang and Kirkham, 1994; Dey and Kar 1995). In any case, the observed decreases in SOD and CAT activities may be because of enzyme inhibition, since $\mathrm{Cd}$ is known to be a potential enzyme inhibitor (Das et al., 1997; Benavides et al., 2005). Our results support the findings of Schutzendubel et al. (2001) who reported a severe suppression of SOD and CAT, and an almost complete loss of ascorbate peroxidase activity in pine roots after 48 $\mathrm{h}$ of exposure to $50 \mu \mathrm{M} \mathrm{Cd}$. However, contrasting results such as either fluctuation or increase in the activities of these enzymes under $\mathrm{Cd}$ stress have also been found (Dixit et al., 2001; Zhang et al., 2007). Although the increase in these enzyme activities has also been linked to the metal tolerance of plants (Zhang et al., 2007), the Cd stress in the present study was accompanied by a weakening of ROS detoxification systems, thus increasing the chances of their accumulation in plant tissues.

Lead-induced increase in SOD activity suggests that due to imposition of $\mathrm{Pb}$ stress, de novo synthesis of enzymatic protein may have occurred which would be more pronounced in root tissues. Similar elevation in SOD activity was also reported in other systems under $\mathrm{Pb}$ stress (e.g., Lozano et al., 1996; Verma and Dubey, 2003). A decreased superoxide concentration is thus to be expected, but in parallel with an increased production of $\mathrm{H}_{2} \mathrm{O}_{2}$. Peroxidases should play a more significant role than CAT in detoxifying the produced $\mathrm{H}_{2} \mathrm{O}_{2}$ since the activity of POX increased, in contrast to that of CAT. That augmentation might be due to increased release of 
peroxidases localized in cell walls as has been reported in rice under $\mathrm{Pb}$ stress (Verma and Dubey, 2003) and also under other stress situations (Mittal and Dubey, 1991; Zhang and Kirkham, 1994; Dey and Kar 1995). Increase in POX activity is now used as a biomarker of heavy metal stress (Zhang et al., 2007).

In the case of $\mathrm{Cd}$ stress, the protection against superoxide and $\mathrm{H}_{2} \mathrm{O}_{2}$ becomes weakened due to the decline in activities of SOD and catalase which may favour the elevated steady state levels of $\mathrm{H}_{2} \mathrm{O}_{2}$ and superoxide. These two ROS can react in presence of transition metal ions to produce the hydroxyl radical (Elstner, 1982). In the case of $\mathrm{Pb}$, even though there was some protection against superoxide, the $\mathrm{H}_{2} \mathrm{O}_{2}$ detoxification mechanism was poor. In aerobic cells, hydroxyl radicals are known to be formed from $\mathrm{H}_{2} \mathrm{O}_{2}$ in presence of transition metal ions (Halliwell and Gutteridge, 1999). In aerobic cells, the hydroxyl radical is known to be the most potentially toxic species. The unsaturated fatty acid components of membrane lipids are highly susceptible to hydroxyl radical attack and are peroxidized in its presence. Therefore, lipid peroxidation is the consequence of free radical mediated reactions in aerobic cells and is a good indicator of prevalence of oxidative stress (Kappus, 1985). In this study, even though total peroxide level was not determined, increased levels of MDA with increasing $\mathrm{Cd}$ and $\mathrm{Pb}$ concentrations were found. In the case of $\mathrm{Cd}$ stress, there was a continuous increase in the MDA level both in roots and shoots with increasing metal concentration, but in $\mathrm{Pb}$ stress, the MDA level peaked at $200 \mu \mathrm{M}$ of $\mathrm{Pb}$ in shoots with no appreciable changes at higher concentrations. This is probably because peroxidizable fatty acid content becomes limiting. Further studies involving membrane lipid analyses and measurement of lipophilic antioxidant levels in the shoot tissues subjected to $\mathrm{Pb}$ stress will clarify this point in the future. Thus the increased MDA indicates the prevalence of oxidative stress and perhaps this may be one of the possible mechanisms by which toxicity due to $\mathrm{Cd}$ and $\mathrm{Pb}$ stress could be manifested in plant tissues. Probably this oxidative stress situation might have occurred due to the alterations in the activities of the antioxidative enzymes. However, prevalence of oxidative stress situation can be conclusively substantiated by measuring the steady state levels of ROS in the tissues.

The sharp decline in CAT activity in roots than in shoots both in presence of $\mathrm{Cd}$ and $\mathrm{Pb}$, the complete loss of SOD activity in roots of Cd-treated seedlings and the sharp induction in SOD activity in $\mathrm{Pb}$-treated roots may be due to higher accumulation of these metals in roots, as has been detected in rice for $\mathrm{Cd}$ (Shah et al., 2001) and $\mathrm{Pb}$ (Verma and Dubey, 2003). Whereas CAT was found to be declining in root as well as in shoot tissues, both under $\mathrm{Cd}$ and $\mathrm{Pb}$ stress, the other two enzymes showed different trends in two different metal stress, except for POX activity in shoots under $\mathrm{Pb}$ stress. Thus we presume that the decline in CAT activity was the key behind the $\mathrm{Cd}$ - and $\mathrm{Pb}$-induced oxidative stress. However, the roles of enzymes involved in ascorbate-glutathione cycle cannot be underestimated. Therefore, analysis of these enzyme activities and determination of the contents of low molecular weight antioxidants like ascorbate and glutathione will be helpful in drawing any such conclusion. Since no nutrient solution was supplemented for growing the seedlings for $7 \mathrm{~d}$, the results of this study can be taken as reference for analyzing any antagonistic or synergistic effects of nutrients with $\mathrm{Cd}$ or $\mathrm{Pb}$ toxicity. At the same time the single effects of these metals on antioxidative enzyme activities, as herein reported, will also be helpful in co-contamination studies, since $\mathrm{Cd}$ and $\mathrm{Pb}$ seldom occur in isolation in the polluted soil environment.

Acknowledgements: The authors are thankful to Prof. S. Nanda, Vice-Chancellor, Fakir Mohan University, Balasore-756019, India for motivating and providing the necessary facilities to carry out the work. One of us (SKD) is thankful to Prof. M. Kar and Dr. P.K. Mohapatra of P.G. Department of Botany, Utkal University, Bhubaneswar-751004, India, for their valuable suggestions in revising the manuscript.

\section{REFERENCES}

Aebi H (1974) Catalase. In: Bergmeyer HU (ed), Methods of Enzymatic Analysis, pp.673-684. Academic Press, New York.

Asada K, Takahasi M (1987) Production and scavenging of active oxygen in photosynthesis. In: Kyle DJ, Osmond C, Arntzen CJ (eds), Photoinhibition, pp.227297. Elsevier, New York.

Baisak R, Rana D, Acharya PBB, Kar M (1994) Alterations in the activities of active oxygen scavenging enzymes 
of wheat leaves subjected to water stress. Plant Cell Physiol. 35:489-495.

Balestrasse KB, Benavides MP, Gallego SM, Tomaro ML (2003) Effect of cadmium stress on nitrogen metabolism in nodules and roots of soybean plants. Funct. Plant Biol. 30:57-64.

Benavides MP, Gallego SM, Tomaro ML (2005) Cadmium toxicity in plants. Braz. J. Plant Physiol. 17:21-34.

Chaoui A, Mazhoudi S, Ghorbal MH, El Ferjani E (1997) Cadmium and zinc induction of lipid peroxidation and effects on antioxidant enzyme activities in bean (Phaseolus vulgaris L.). Plant Sci. 127:139-147.

Das K, Samanta L, Chainy GBN (2000) A modified spectrophotometric assay of superoxide dismutase using nitrite formation by superoxide radicals. Ind. J. Biochem. Biophys. 37:201-204.

Das P, Samantaray S, Rout GR (1997) Studies on cadmium toxicity in plants: a review. Environ. Pollution 98:29-36.

Dey SK, Kar M (1995) Antioxidant efficiency during callus initiation from mature rice embryo. Plant Cell Physiol. 36:543-549.

Dixit V, Pandey V, Shyam R (2001) Differential oxidative responses to cadmium in root and leaves of pea (Pisum sativum L cv. Azad). J. Exp. Bot. 52:1101-1109.

Eick MJ, Peak JD, Brady PV, Pesek JD (1999) Kinetics of lead absorption/desorption on goethite residence time effect. Soil Sci. 164:28-39.

Elstner EF (1982) Oxygen activation and oxygen toxicity. Annu. Rev. Plant. Physiol. 33:73-96.

Elstner EF, Wagner GA, Schutz W (1988) Activated oxygen in green plants in relation to stress situations. Curr. Top. Plant Biochem. Physiol. 7:159-187.

Gomez KA, Gomez AA (1984) Statistical Procedure for Agricultural Research. $2^{\text {nd }}$ ed. Wiley Interscience Publication, New York.

Halliwell B, Gutteridge JMC (1999) Free Radicals in Biology and Medicine. $4^{\text {th }}$ ed. Oxford University Press, New York.

Heath RL, Packer L (1968) Photooxidation in isolated chloroplasts. I. Kinetics and stoichiometry of fatty acid peroxidation. Arch. Biochem. Biophys. 125:189-198.

Kappus H (1985) Lipid Peroxidation: Mechanisms, analysis, enzymolog y and biological relevance. In: Sies H (ed), Oxidative Stress, pp.273-310. Academic Press, London.

Kar M, Feierabend J (1984) Metabolism of activated oxygen in detached wheat and rye leaves and its relevance to the initiation of senescence. Planta 160:385-391.

Kastori R, Petrovic M, Petrovic N (1992) Effect of excess lead, cadmium, copper and zinc on water relations in sunflower. J. Plant Nutr. 15:2427-2439.

Landis WG, Yu M (1999) Introduction to Environmental Toxicology: Impacts of Chemicals upon Ecological Systems. $2^{\text {nd }}$ ed. Lewis Publishers, New York.

Lowry OH, Rosebrough NJ, Farr AL, Randell RJ (1951) Protein measurement with Folin-phenol reagent. J. Biol. Chem. 193:265-275.

Lozano R, Azcon R, Palma JM (1996) SOD and drought stress in Lactua sativa. New Phytol. 136: 329-331.

Malecka A, Jarmuszkiewicz W, Tomaszewska B (2001) Antioxidative defense to lead stress in sub cellular compartments of pea root cells. Acta Biochim. Polon. 48:687-698.

Mittal R, Dubey RS (1991) Behaviour of peroxidases in rice: changes in enzymatic activity and isoforms in relation to salt tolerance. Plant Physiol. Biochem. 29:3140.

Oliveira da Silva AL, Barrocas PRG, Jacob SC, Moreira JC (2005) Dietary intake and health effects of selected toxic elements. Braz. J. Plant Physiol. 17:79-93.

Pinto E, Sigaud-Kutner TCS, Leitão MAS, Okamoto OK, Morse D, Colepicolo P (2003) Heavy metal-induced oxidative stress in algae. J. Phycol. 39:1008-1018.

Sanita di Toppi L, Gabbrielli R (1999) Response to cadmium in higher plants. Environ. Exp. Bot. 41:105-130.

Schutzendubel A, Schwanz P, Teichmann T, Gross K, Langenfeld-Heyser R, Godbold A, Polle A (2001) Cadmium-induced changes in antioxidative systems, $\mathrm{H}_{2} \mathrm{O}_{2}$ content and differentiation in Scots pine (Pinus sylvestris) roots. Plant Physiol. 127:887-898.

Shah K, Kumar RG, Verma S, Dubey RS (2001) Effect of cadmium on lipid peroxidation, superoxide anion generation and activities of antioxidant enzymes in growing rice seedlings. Plant Sci. 161:1135-1144.

Stohs SJ, Bagchi D (1995) Oxidative mechanisms in the toxicity of metal ions. Free Rad. Biol. Med. 18:321-336.

Verma S, Dubey RS (2003) Lead toxicity induces lipid peroxidation and alters the activities of antioxidant enzymes in growing rice plants. Plant Sci. 164:645-655.

Zhang J, Kirkham MB (1994) Drought-stress induced changes in activities of superoxide dismutase, catalase and peroxidase in wheat species. Plant Cell Physiol. 35:785-791.

Zhang F, Wang Y, Lou Z, Dong J (2007) Effect of heavy metal stress on antioxidative enzymes and lipid peroxidation in leaves and roots of two mangrove plant seedlings (Kandelia candel and Bruguiera gy mnorrhiza). Chemosphere 67:44-50. 